\title{
PENGARUH KONSUMSI YOGURT YANG DIBUAT DENGAN KULTUR DUA BAKTERI (Sterptococcus thermophillus DAN Lactobacillus bulgaricus) DAN TIGA BAKTERI (Sterptococcus thermophillus, Lactobacillus bulgaricus DAN Lactobacillus acidophilus) TERHADAP KADAR KOLESTEROL SERUM DARAH TIKUS
}

\author{
Safri Ishmayana ${ }^{\mathrm{a} *}$, Asep Juanda ${ }^{\mathrm{a}}$, O. Suprijana ${ }^{\mathrm{a}}$, Sadiah Djajasoepena ${ }^{\mathrm{a}}$, Idar Idar ${ }^{\mathrm{b}}$, \\ Saadah D. Rachman ${ }^{\text {a }}$ \\ ${ }^{a}$ Departemen Kimia, Fakultas Matematika dan Ilmu Pengetahuan Alam, Universitas Padjadjaran, Jln. Raya \\ Bandung-Sumedang km. 21, Jatinangor, Sumedang, Jawa Barat 45363 \\ ${ }^{\mathrm{b}}$ Sekolah Tinggi Farmasi Bandung, Jln. Soekarno - Hatta No.754, Bandung, Jawa Barat 40617 \\ *Alamat Korespondensi: ishmayana@ unpad.ac.id
}

\begin{abstract}
Abstrak: Tingginya kadar kolestrol serum darah berhubungan dengan meningkatnya resiko aterosklerosis dan penyakit jantung koroner. Produk susu terfermentasi seperti yogurt dapat menurunkan kadar kolesterol serum darah sehingga dapat meningkatkan resiko kedua penyakit tersebut. Penelitian ini bertujuan untuk mempelajari pengaruh konsumsi yogurt yang dibuat dengan dua dan tiga bakteri terhadap kadar kolesterol serum darah tikus putih. Pada percobaan ini 15 tikus putih jenis Wistar dibagi menjadi empat kelompok, masing-masing kelompok tiga atau empat ekor. Kelompok pertama diberi pakan dan air, kelompok kedua diberi pakan dan susu murni, kelompok ketiga diberi pakan dan yogurt 2 bakteri sedangkan kelompok keempat diberi pakan dan yogurt 3 bakteri. Perlakuan diet diberikan selama 56 hari, setiap dua minggu contoh darah tikus diambil dan ditentukan kadar kolesterol serumnya dengan metode Lieberman-Burchard. Hasil penelitian ini menunjukkan adanya efek hipokolesterolemik, dan efek paling baik teramati pada periode ketiga untuk grup 4, dimana tikus diberi pakan dan yogurt yang dibuat dengan kultur 3 bakteri dimana kadar kolesterolnya sebesar 16,57\% lebih rendah dibandingkan kontrol.
\end{abstract}

Kata kunci: yogurt,kolesterol, hipokolesterolemik

Abstract: High cholesterol level in blood serum is related to higher atherosclerosis and coronary heart disease. Fermented dairy product such as yogurt can reduce cholesterol level in blood serum and therefore can reduce risk for both of the diseases. The present study was intended to investigate the effect of yogurt made with two and three bacterial cultures consumption on cholesterol level in blood serum of white rat. In the present study, 15 white Wistar rats were divided into four groups with each group consists of three or four rats. The first group were fed with feed and water, the second group were fed with feed and milk, the third group were fed with feed and yogurt made with 2 bacterial culture and the fourth group were fed with feed and yogurt made with 3 bacterial culture. The experiment was conducted for 56 days and every two weeks the rat blood samples were drawn and the cholesterol levels were determined using Lieberman-Burchard method. The resuts of the present study indicate that the both of the yogurt gave hypocholesterolemic effect, and the highest effect was observed at the $3^{\text {rd }}$ period in group 4, which is rats given feed and yogurt made with 3 bacterial culture in which the cholesterol level was $16.57 \%$ lower compared to control.

Keywords: yogurt, cholesterol, hypocholesterolemic

\section{PENDAHULUAN}

Konsumsi oral bakteri asam laktat (BAL) sebagai probiotik dapat membantu mengatasi masalah-masalah pencernaan seperti intoleransi laktosa, diare yang disebabkan oleh bakteri, sembelit, radang usus, dan alergi makanan. Selain itu, konsumsi probiotik ini dilaporkan dapat menurunkan kadar kolesterol serum (St-Onge et al., 2000; Baroutkoub et al., 2010). BAL yang umumnya digunakan sebagai probiotik diantaranya adalah Lactobacillus acidophilus, Lactobacillus casei, Bifidobacterium bifidum dan Bifidobacterium longum (Lourens-Hattingh \& Viljoen, 2001).

Beena \& Prasad (1997) membandingkan pengaruh yogurt yang diinokulasi dengan 2 BAL ( $S$. thermophillus dan L. bulgaricus) dan yogurt yang mengandung 3 BAL (S. thermophillus, L. bulgaricus dan B. bifidum) terhadap konsentrasi kolesterol serum darah tikus. Tiap-tiap yogurt diberikan diberikan pada tikus secara ad libitum selama 30 hari. Hasil penelitian mereka menunjukkan bahwa kedua jenis yogurt dapat menurunkan kadar kolesterol total serum darah secara signifikan.

Selain itu, penelitian lain yang dilakukan oleh Akalin et al. (1997) menguji pengaruh yogurt yang dibuat dengan kultur 2 BAL (S. thermophillus dan $L$. bulgaricus) dan 2 BAL (S. thermophillus dan $L$. acidophilus) terhadap kadar kolesterol total, triasilgliserol dan lipoprotein. Pada hari ke-28, tikus yang diberi yogurt $L$. acidophilus menunjukkan konsentrasi kolesterol total 22\% lebih rendah dibandingkan kelompok kontrol. Setelah 56 hari, 
tikus yang diberi yogurt L. acidophilus menunjukkan konsentrasi kolesterol total $31 \%$ lebih rendah dibandingkan kontrol dan $26 \%$ lebih rendah dibandingkan tikus yang diberi yogurt yang difermentasi dengan $S$. thermophillus dan $L$. bulgaricus.

Penelitian kelompok kami telah membuat yogurt dengan menggunakan kultur dua BAL $(S$. thermophillus dan L. bulgaricus) dan tiga bakteri ( $S$. thermophillus, L. bulgaricus dan L. acidophilus) (Rachman dkk. 2015). Pada penelitian kali ini kami melanjutkan untuk melihat pengaruh kedua yogurt tersebut terhadap kadar kolesterol serum darah.

\section{BAHAN DAN METODE}

Alat

Alat-alat yang digunakan pada penelitian ini antara lain adalah disposable syringe, freezer, inkubator, laminar flow, neraca analitis, neraca teknis, pH meter, pipet mikro, sentrifugasi, spektrofotometer dan alat-alat gelas yang umum digunakan di lanboratorium.

Bahan

Hewan uji

Tikus yang digunakan pada penelitian ini adsalah tikus betina putih jenis Wistar yang diperoleh dari Departemen Biologi, FMIPA, Universitas Padjadjaran.

\section{Kultur bakteri}

Bakteri yang digunakan adalah $L$. bulgaricus, $S$. thermophilus, dan L. acidophilus yang diperoleh dari laboratorium Mikrobiologi ITB.

\section{Bahan kimia}

Bahan-bahan yang digunakan pada penelitian ini antara lain: agar bacto, asam sulfat pekat, asetat anhidrida, air suling, ekstrak ragi, kolesterol, kloroform, MRS broth, pepton, susu skim dan susu sapi murni.

\section{Pembuatan kultur starter tunggal}

Ke dalam tiga botol vial yang berisi $5 \mathrm{~mL}$ susu skim yang telah dipasteurisasi masing-masing diinokulasi dengan satu ose $L$. bulgaricus, S. thermophilus dan L. acidophilus. Masing-masing botol kemudian diinkubasi selama 24 jam pada suhu $37^{\circ} \mathrm{C}$, kemudian masing-masing dipindahkan ke dalam $50 \mathrm{~mL}$ susu skim yang telah dipasteurisasi pada suhu $85^{\circ} \mathrm{C}$ selama 10 menit dan kembali diinkubasi selama 24 jam pada suhu $37^{\circ} \mathrm{C}$. Selanjutnya kultur dapat digunakan.

\section{Pembuatan kultur starter campuran}

$\mathrm{Ke}$ dalam $50 \mathrm{~mL}$ susu skim yang telah dipasteurisasi pada suhu $85^{\circ} \mathrm{C}$ selama 10 menit dimasukkan kultur starter tunggal $S$. thermophilus : $L$. bulgaricus $=1: 1$ (v:v) dan $S$. thermophilus : $L$. bulgaricus : L. acidophilus $=1: 1: 1$ ( v:v:v).
Kemudian masing-masing campuran dihomogenkan dan diinkubasi pada suhu $40^{\circ} \mathrm{C}$ selama 10 jam sampai terbentuk kultur starter campuran. Selanjutnya kultur starter ini dapat disimpan dalam lemari pendingin pada suhu $4{ }^{\circ} \mathrm{C}$.

\section{Pembuatan yogurt}

Susu murni yang akan difermentasi dipasteurisasi terlebih dahulu pada suhu $85^{\circ} \mathrm{C}$ selama 10 menit, kemudian dimasukkan ke dalam labu Erlenmeyer masing-masing $50 \mathrm{~mL}$. Ke dalamnya dimasukkan kultur starter campuran $S$. thermophilus : L. bulgaricus $=1: 1$ (v:v) dan $S$. thermophilus $: L$. bulgaricus : L. acidophilus $=1: 1: 1$ ( v:v:v), kemudian diinkubasi pada suhu $40^{\circ} \mathrm{C}$ selama 10 jam sampai terbentuk yogurt.

\section{Pengelompokan tikus}

Tikus putih yang berjumlah lima belas ekor dibagi menjadi 4 kelompok. Kelompok 1 diberi pakan dan air, kelompok 2 diberi pakan dan susu murni, kelompok 3 diberi pakan dan yogurt 2 bakteri, dan kelompok 4 diberi pakan dan yogurt 3 bakteri. Untuk kelompok 2, 3 dan 4 tidak diberi air. Tikus diberi diet sebanyak $10 \mathrm{~g} /$ hari/ekor pakan dan 50 $\mathrm{mL} /$ hari/ekor untuk air atau susu atau yogurt selama 56 hari. Setiap 2 minggu sekali, berat badan tikus ditimbang dan dilakukan pengambilan contoh darah.

\section{Pengambilan contoh darah}

Tikus dipuasakan selama minimal 12 jam. Contoh darah diambil dengan jarum suntik melalui ekor dan ditempatkan dalam tabung sentrifugasi steril, lalu disentrifugasi dengan kecepatan $1207 \mathrm{~g}$ selama 15 menit. Serum yang didapat disimpan pada suhu $-20^{\circ} \mathrm{C}$ sampai analisis dilakukan.

\section{Analisis kolesterol total}

\section{Penentuan panjang gelombang maksimum}

Larutan kolesterol standar sebagai stok dibuat dengan konsentrasi $250 \mathrm{mg} / 100 \mathrm{~mL}$ dengan pelarut kloroform. Sebanyak $0,1 \mathrm{~mL}$ diambil kemudian dimasukkan ke dalam tabung reaksi yang kering dan ditambahkan pereaksi Lieberman-Burchard $(2,5 \mathrm{~mL}$ anhidrida astetat dan $0,5 \mathrm{~mL}$ asam sulfat pekat). Penambahan dilakukan dalam ruang asam pada kondisi dingin. Campuran disimpan selama 30 menit kemudian diukur serapannya pada panjang gelombang $500-700 \mathrm{~nm}$.

\section{Pembuatan kurva baku}

Larutan standar kolesterol dibuat dengan variasi konsentrasi 20, 40, 60, 80, 100, 120 dan 140 mg/100 $\mathrm{mL}$. Masing-masing diambil $0,1 \mathrm{~mL}$ dan ditambahkan dengan pereaksi Lieberman-Burchard. Kemudian diukur serapannya pada panjang gelombang $630 \mathrm{~nm}$ (sesuai hasil penentuan panjang gelombang maksimum), kemudian dibuat grafik serapan terhadap konsentrasi. 


\section{Analisis contoh}

Serum diambil sebanyak $0,1 \mathrm{~mL}$ dan ditambahkan dengan pereaksi Lieberman-Burchard kemudian diukur serapannya pada panjang gelombang $630 \mathrm{~nm}$. Konsentrasi kolesterol dalam sampel dihitung dengan memplotkan nilai absorbansi pada kurva baku.

\section{HASIL DAN PEMBAHASAN}

\section{Pembuatan kultur starter}

Pada pembuatan kultur starter, baik kultur starter tunggal maupun campuran digunakan susu skim sebagai media. Sedangkan pada pembuatan yogurt media yang digunakan adalah susu sapi murni. Hal ini dikarenakan susu skim memiliki kandungan nutrisi yang lebih stabil dibandingkan susu murni. Pembuatan kultur starter tidak mengutamakan produk, sehingga media kultur bisa saja berbeda dengan media fermentasi.

Banyaknya inokulum yang ditambahkan pada media fermentasi adalah $10 \%$ dari volume media fermentasi. Oleh karena itu, pada pembuatan kultur starter dilakukan dua tahap propagasi. Pada tahap pertama dilakukan inokulasi pada volume $5 \mathrm{~mL}$, kemudian diinokulasikan kembali pada volume media $50 \mathrm{~mL}$
Pada penelitian ini digunakan dua macam kultur starter campuran yaitu kultur starter dua bakteri $(S$. thermophilus dan $L$. bulgaricus) dengan perbandingan 1:1 (v:v) dan kultur starter tiga bakteri (S. thermophilus, L. bulgaricus dan L. acidophilus) dengan perbandingan 1:1:1 (v:v:v). Kultur starter yang dihasilkan masing-masing memiliki pH 4,90 dan 4,79 untuk kultur starter 2 dan 3 bakteri.

\section{Pembuatan Yogurt}

Selama periode perlakuan diet, dilakukan pembuatan yogurt sebanyak 20 kali dengan rentang pembuatan setiap tiga hari. Hasil pengukuran $\mathrm{pH}$, disajikan pada Tabel 1 .

Data pada Tabel 1 terlihat bahwa yogurt yang dihasilkan, baik yogurt 2 bakteri ataupun yogurt 3 bakteri, mempunyai rentang $\mathrm{pH} 4,5$ - 4,9 yang menunjukkan bahwa yogurt tersebut layak dikonsumsi dengan $\mathrm{pH}$ mendekati nilai $\mathrm{pH}$ yang disarankan oleh Food Standards Australia New Zealand (2014) yaitu sebesar 4,5.

Pada $\mathrm{pH}$ tersebut, ketiga jenis bakteri masih dapat tumbuh. S. thermophilus, L. bulgaricus dan $L$. acidophilus masih dapat tumbuh sehingga mampu untuk bertahan hidup melewati lambung (Marteau et al., 1997).

Tabel 1 Nilai pH yogurt yang dibuat selama periode percobaan

\begin{tabular}{ccc}
\hline No. & $\begin{array}{c}\mathrm{pH} \text { Yogurt } \\
\text { 2 bakteri }\end{array}$ & $\begin{array}{c}\mathrm{pH} \text { Yogurt } \\
\text { 3 bakteri }\end{array}$ \\
\hline 1. & 4,62 & 4,51 \\
2. & 4,97 & 4,83 \\
3. & 4,63 & 4,54 \\
4. & 4,62 & 4,52 \\
5. & 4,96 & 4,82 \\
6. & 4,71 & 4,61 \\
7. & 4,62 & 4,53 \\
8. & 4,65 & 4,54 \\
9. & 4,73 & 4,55 \\
10. & 4,96 & 4,75 \\
11. & 4,93 & 4,93 \\
12. & 4,93 & 4,82 \\
13. & 4,61 & 4,51 \\
14. & 4,67 & 4,51 \\
15. & 4,97 & 4,82 \\
16. & 4,72 & 4,75 \\
17. & 4,90 & 4,83 \\
18. & 4,98 & 4,82 \\
19. & 4,79 & 4,93 \\
20. & 4,79 & 4,87 \\
\hline & &
\end{tabular}




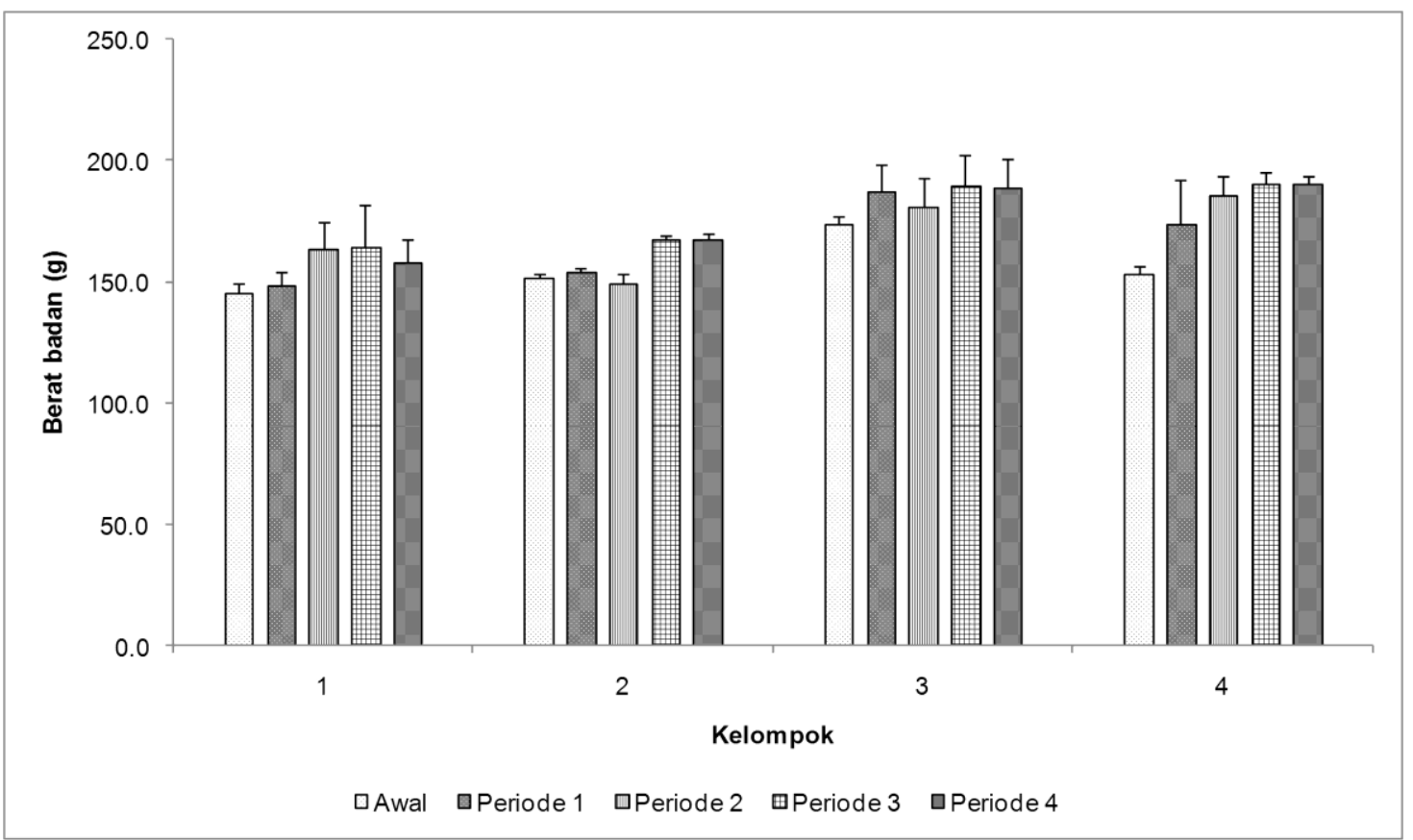

Gambar 1 Berat badan tikus rata-rata untuk empat kelompok tikus pada awal masa perlakuan dan 4 periode percobaan. Kelompok 1 adalah tikus yang diberi pakan dan air, kelompok 2 adalah tikus yang diberi pakan dan susu murni, kelompok 3 adalah tikus yang diberi pakan dan yogurt 2 bakteri sedangkan kelompok 4 adalah tikus yang diberi pakan dan yogurt 3 bakteri.

\section{Pengaruh Diet terhadap Berat Tikus}

Data pengaruh diet terhadap berat badan tikus disajikan pada Gambar 1. Dari Gambar 1 dapat dilihat bahwa tikus yang dipelihara cenderung mengalami peningkatan berat badan. Hal ini menunjukkan bahwa tikus-tikus dalam keadaan sehat. Pada akhir periode diet (periode 4) tikus-tikus yang diberi yogurt 2 bakteri (kelompok 3) dan tikus-tikus yang diberi yogurt 3 bakteri (kelompok 4) mengalami penambahan berat badan yang lebih besar dibandingkan dengan tikus yang diberi pakan dan air (kelompok 1). Namun, tidak ada perbedaan berat badan antara tikus-tikus kelompok 3 dengan tikus kelompok 4.

\section{Analisis kadar kolesterol serum darah}

Untuk menentukan kadar kolesterol serum darah digunakan metode Lieberman-Burchard. Reaksi pada metode ini peka terhadap air dan cahaya, oleh karena itu tabung reaksi yang digunakan harus bersih dan kering serta dilakukan pada penangas es karena reaksinya bersifat eksoterm sehingga dapat terjadi pembentukan arang dari protein yang terdapat dalam serum dan menyebabkan larutan menjadi berwarna coklat sampai hitam. Jika reaksi berlangsung baik, akan terbentuk larutan berwarna hijau.

Pada penentuan kadar kolesterol dengan metode Lieberman-Burchard secara spektrofotometri, absorban contoh diukur dengan membandingkan terhadap larutan blanko. Pada blanko ditambahkan 0,1 mL air karena serum darah mengandung air yang dapat mempengaruhi warna yang terbentuk.
Penambahan air pada larutan blanko akan diperoleh warna yang mendekati contoh.

Untuk penentuan kadar kolesterol dengan metode Lieberman-Burchard, terlebih dahulu dilakukan penentuan panjang gelombang maksimum. Sebanyak 0,1 $\mathrm{mL}$ larutan stok diambil dan ditambahkan dengan pereaksi Lieberman-Burchard, lalu serapannya diukur dengan spektrofotometer pada panjang gelombang $500-700 \mathrm{~nm}$. Hasil pengukuran disajikan pada Gambar 2. Gambar 2 menunjukkan bahwa panjang gelombang maksimum untuk metode Lieberman-Burchard adalah $630 \mathrm{~nm}$.

Serum dari contoh darah periode 1 (dua minggu pertama), periode 2 (dua minggu kedua), periode 3 (dua minggu ketiga) dan periode 4 (dua minggu keempat) dianalisis dengan metode spektrofotometri menggunakan reagen Lieberman-Burchard dan diukur serapannya pada panjang gelombang $630 \mathrm{~nm}$. Hasil analisis kadar kolesterol ditunjukkan pada Gambar 3.

Pada periode 1 dan periode 2, tikus-tikus yang diberi yogurt 2 bakteri (kelompok 3) menunjukkan kadar kolesterol yang lebih rendah dibandingkan tikus kelompok 1 (kontrol). Sedangkan tikus yang diberi yogurt 3 bakteri (kelompok 4) menunjukkan kadar kolesterol yang lebih tinggi dibandingkan kontrol.

Yogurt 2 bakteri memberikan penurunan hingga $9,51 \%$ pada periode 1 , sedangkan pada periode 2 terjadi penurunan sebesar $10,77 \%$. Pada periode 3 dan 4 yogurt 2 bakteri maupun 3 bakteri memberikan efek hipokolesterolemik. Pada periode ini, yogurt 2 
bakteri menurunkan kadar kolesterol masing-masing sebesar 15,36 dan 9,64\% sedangkan yogurt 3 bakteri menurunkan kadar kolesterol masing-masing sebesar 16,57 dan 10,92\%. Data ini menunjukkan bahwa dengan periode konsumsi yang lama (mencapai 8 minggu) yogurt 3 bakteri cenderung memberikan efek penurunan kadar kolesterol yang lebih baik dibandingkan yogurt 2 bakteri, meskipun pada periode awal yogurt 3 bakteri tidak menunjukkan kadar kolesteol yang lebih rendah dibandingkan kontrol. Kadar kolesterol yang lebih rendah pada kelompok tikus yang diberi yogurt terjadi karena adanya kemampuan BAL untuk mengabsorpsi kolesterol melalui dinding sel, dekonjugasi asam empedu dan juga hidrolisis asam empedu (Baroutkoub et al., 2010; Dilmi-Bouras, 2006)

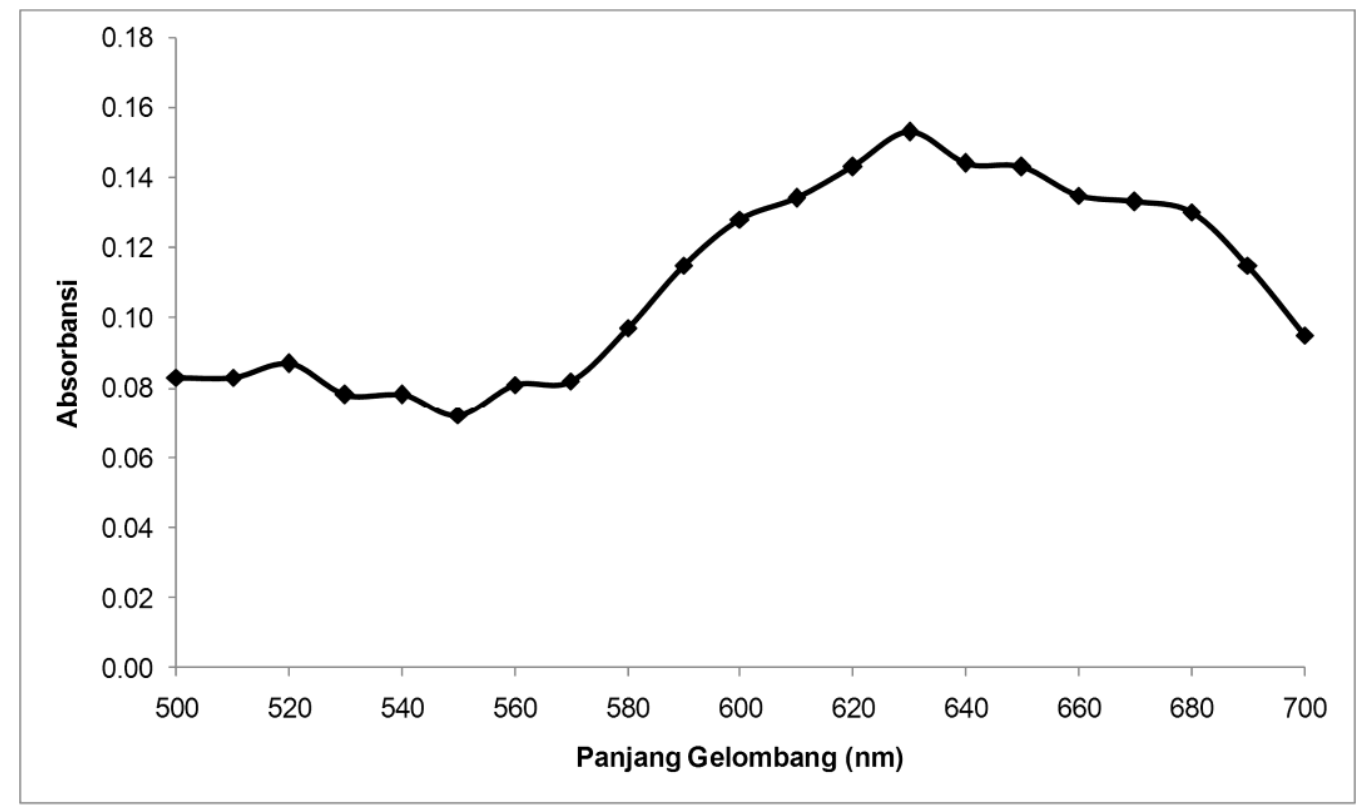

Gambar 2 Nilai absorbansi larutan kolesterol yang ditambahkan dengan reagen Lieberman-Burchard pada panjang gelombang 500 sampai $700 \mathrm{~nm}$.

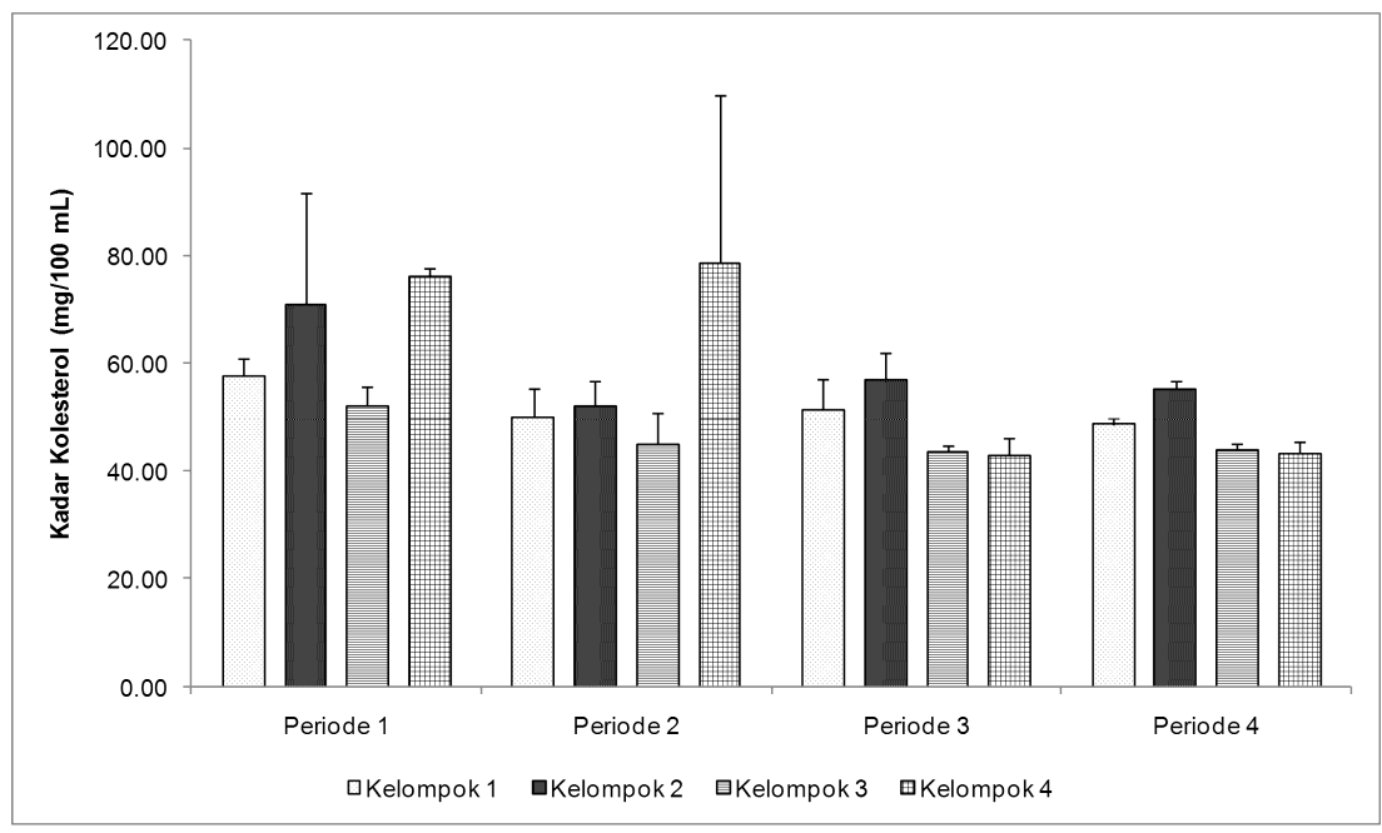

Gambar 3 Kadar kolesterol serum darah rata-rata empat kelompok tikus pada empat periode percobaan yang berbeda. Kelompok 1 adalah tikus yang diberi pakan dan air, kelompok 2 adalah tikus yang diberi pakan dan susu murni, kelompok 3 adalah tikus yang diberi pakan dan yogurt 2 bakteri sedangkan kelompok 4 adalah tikus yang diberi pakan dan yogurt 3 bakteri. 


\section{KESIMPULAN}

Konsumsi yogurt dalam jangka waktu yang lama dapat menurunkan kadar kolesterol serum darah. Pada percobaan ini, yogurt yang dibuat dengan 3 bakteri ( $S$. thermophillus, $L$. bulgaricus dan $L$. acidophilus) menunjukkan efek penurunan kadar kolesterol serum darah yang lebih baik dibandingkan yogurt 2 bakteri (S. thermophillus dan L. bulgaricus). Penurunan kadar kolesterol paling tinggi terdeteksi pada periode ke 3 dengan penurunan sebesar 16,57\% pada tikus yang diberi yogurt 3 bakteri.

\section{Ucapan Terima Kasih}

Kami mengucapkan terima kasih kepada Bpk. U. Juharia dan Bpk. Maman Tardi atas bantuan teknis yang telah diberikan.

\section{DAFTAR PUSTAKA}

Akalin, A.S., Gönç, S. \& Düzel, S. (1997). Influence of yogurt and acidophilus yogurt on serum cholesterol levels in mice. Journal of Dairy Science, 80, 2721-2725.

Baroutkoub, A., Mehdi, R.Z., Beglarian, R., Hassan, J., Zahra, S., Mohammad, M.S. \& Hadi, E.M. (2006). Effects of probiotic yoghurt consumption on the serum cholesterol levels in hypercholestromic cases in Shiraz, Southern Iran. Scientific Research and Essays, 5(16), 2206-2209.

Beena, A. \& Prasad, V. (1997). Effect of yogurt and bifdus yogurt fortifed with skim milk powder, condensed whey and lactose-hydrolysed condensed whey on serum cholesterol and triacylglycerol levels in rats. Journal of Dairy Research. 64, 453-457.

Dilmi-Bouras, A. (2010). Assimilation (in vitro) of cholesterol by yogurt bacteria. Annals of Agricultural and Environmental Medicine, 13, 49-53.

Food Standards Australia New Zealand. (2014). Standard 2.5.3 Fermented milk products.

Lourens-Hattingh, A. \& Viljoen, B.C. (2001). Yogurt as probiotic carrier food. International Dairy Journal. 11, 1-17.

Marteau, P., Minekus, M., Havenaar, R. \& Veld, J.H.J.H.I. (1997). Survival of lactic acid bacteria in a dynamic model of the stomach and small intestine: validation and the effects of bile. Journal of Dairy Science, 80, 1031-1037.

Rachman, S.D., Djajasoepena, S., Kamara, D.S., Idar, I., Sutrisna, R., Safari, A., Suprijana, O., \& Ishmayana, S. (2015). Kualitas yoghurt yang dibuat dengan kultur dua (Lactobacillus bulgaricus dan Streptococcus thermophilus) dan tiga bakteri (Lactobacillus bulgaricus, Streptococcus thermophilus dan Lactobacillus acidophilus), Chimica et Natura Acta, 3(2), 7679.

St-Onge, M.-P., Franworth, E.R. \& Jones, P.J.H. (2000). Consumption of fermented and nonfermented dairy products: effects on cholesterol concentrations and metabolism, American Journal of Clinical Nutrition, 71, 674-681. 